\title{
PROBLEMATIC OF FARMER RIGHTS IN INTERNATIONAL FOOD TRADE
}

\author{
Moch Najib Immanullah, Hernawan Hadi, Emmy Latifah \\ Faculty of Law, Sebelas Maret University \\ e-mail: imanullahnajib@yahoo.com, hernawanhadi@gmail.com,
}

\begin{abstract}
The urgency of this study is to analyze the problem concerning the provision of preventive and repressive protection rights for farmers regarding to the International Food Trade based on Agricultural Law, by using normative legal research, in order to owns a feasible position and competitiveness to the Indonesian Farmers as the subject of International Food Trade. The results of the study shows that the existing regulation has not being able to provide preventive and repressive protection rights for farmers in International Trade. Indonesian Government takes alternative solution by doing the harmonization of Indonesian Law which regulate the international trade, particularly the agricultural trade.
\end{abstract}

Keywords: Problematic, Legal Protection, Farmers Rights, International Trade.

\section{A. INTRODUCTION}

In order to understand the Farmers Rights and its legal protection, both preventive and repressive, it is important to analyze it first regulation concerning the food which a products from the farmers and became one of the international trade objects. Legal politics adjust the agriculture law purposes, as it can seen in the description of Law Number 18 of 2012 on Food, clearly affirmed the food is a major basic human needs which the part of the human rights guaranteed in The Constitution of the Republic of Indonesia of 1945. The Nation has obligation to embody availability, affordability, and the fulfillment of sufficiently, securely, certifiable, and nutritious food, both in national region as well as provincial region until individual equally all over in Republic of Indonesia, by utilize the resources, institutional, and local cultural.

Food is a primary human needs. Food must be available in sufficiently, securely, nutritious, also variously with the affordable price, as well as not contradict 
the religion, beliefs, and culture. Strategic role of farmers not being able to be denied because its position as part of the food producer through its business.

To reach all the goals, it is necessary to establish a food system which give a protection, both to the producer and the consumer. The food consumption fulfillment must prioritizes the domestic production by utilize the resources optimally. In context, farmers rights must obtain protection to implement the obligation as the party which must actively contribute the sovereignty, independency, endurance food.

Whenever the goals fulfilled, it is possible the farmer by its business perform the food export. Farmers will experience many obstacles which requires attention from its farmer, government, and community. The major issue is the readiness of the farmers to experience the competition in the global food trade.It can not be denied that the ability of the farmers became subject in global food trade. Indonesia as an agricultural country has an advantage as the producer of the strategic food as rice, soybean, beef, chili. The result of its production encourage the national economic, noted in 2010 until 2014, economy growing up to 6,0 \% with the specific from agriculture, forestry, fishery sector present totaling 13,38 \% (M. Zainul Abidin, 2015).

Contribution from agriculture sector towards the national income is huge, in form of directly donation as well as Gross Domestic Product, employment, food provision, industry raw material, community income improvement, foreign exchange, poverty reduction, as well as indirectly contribution. In Gross Domestic Product, agriculture sector grows up to $3 \%$ per year, namely until $4.8 \%$ in 2009 regarding to better improvement and increase in plantation products when the crisis of global food. ( Sri Hery Susiolowati, 2009 ).

Although the huge contribution came from agriculture sector, the development of agriculture still confronted to crucial problems. The development of food products and consumer demand, especially in global region. The agriculture progress in Indonesia is lower than another country meanwhile Indonesia ranked 122 
from 183 countries. In ASEAN Region, Indonesia Rank below Singapore (1), Thailand (13), Malaysia (20), Brunei Darussalam (88), Vietnam (92), Laos (165). Commodities that have high competitiveness are palm oil, oilcake, and the most not competitiveness is sheepskin. ( Bambang Irawan, 2014).

The weaknesses product and commodities of agriculture sector seen from the number of import product that still high. The dependency of import and agriculture commodity may remain the problem in each year. Indonesia as an agriculture country that own exuberating resources must import 29 food commodity ( Setjen DPR RI, 2011). These 29 commodity consists of rice, corn, soybean, wheat, flour, sugar, cane, chicken meat, beef, salt, butter, cooking oil, milk, garlic, coconut, coffee, chili, tobacco, potatoes, cassava, and so on. Some of these commodity can be produced in Indonesia.

The efforts to develop the competitiveness of products and agriculture commodity must be the major governments policy in business and industry. Enhancement the agriculture commodity must be inseparable from its transformation, simultaneously to support the economic transformation. (Bambang Irawan, 2014: 2). According to this fact, Law Number 19 of 2013 on Farmers Protection and Empowerment established. Complexity in global trade, including the food trade with the farmers as its subject, requires governments to regulate the trade with the goals to secure the subject of global trade, one of them is farmer, to be protected from fraudulent, discriminatory, incommensurate position, which contained in Law Number 7 of 2014 on Trade. The main problem is the regulation, Food Regulation, Farmers Protection and Empowerment Regulation, Trade Regulation were being able to give the protection to the rights of farmers, in preventive and repressive way, as the subject of global trade, which has neutral position and high competitiveness.

\section{B. RESEARCH METHODS}

This research is a normative research by using the secondary data from primary legal materials, which Food Regulation, Farmers Protection and 
Empowerment Regulation, and Trade Regulation. Secondary data came from journals and articles which regulate farmers protection in global trade. Data obtained by literature study. The data from secondary sources validated by source critical. Data analysis by using legal interpretation that are historic, systematic, and grammatical interpretation.

\section{DISCUSSION}

Food has a juridical terminology as all things derived from agriculture products, plantation, forestry, fishery, animal husbandry, water, both made or not made as food or drink to human consumption, including food materials, food raw materials, and others materials which use in preparation, processing, manufacturing food or drinks. Farmers is a vital subject in food trade, because farmers who done its business in food section. Meanwhile, in Food Regulation, food trade is a each activity or a string of in order to selling and/or purchase food, including offers to sell food and other activity which regarding alienation food to achieve price. One of in these activity is food export, which activity that issue food out from lands, seas, air of Indonesia, Zona Economy Exclusive (ZEE), and continental shelf.

Food export can be done by noticing the food needs in country and national interests. Primary food export can be done after the national food needs and reserve food fulfilled ( Article 34).Each person who export food, has responsible for security, quality, and nutritious food in order to fulfilled other country's requirements. Food export can be done with the provision of regulation ( Article 35 ), based on Trade Regulation and its implementation.

Food import only can be done if the domestic food production is insufficient. Adequacy of domestic food production and food reserve is regulated by government or minister who has an obligation to implement government's duty in food sector (Article 36). Food import which done to fulfilled the consumption needs must satisfy the requirements of security, quality, nutritious, and not contradicted with religion, beliefs, and culture (Article 37). Food import must satisfy expiry requirements and 
quality of food (Article 38). Government set the policy and regulation regarding Food Import that not give a negative impact to the farmers business, production empowerment, farmers welfare, fisherman, fish cultivation, and traders man in macro and micro food. Food import done appropriate with the provision of its regulation.

Government has an obligation to hold a training to marketing party. The training aims that each parties has an ability to implement the marketing procedure well. Government and/or Local Government conducting the promotion to increase the local food quality. Government and/or Local Government conducting the promotion in another country to develop the food marketing (Article 50).

Government has an obligation to stabilize the supply and price of primary food in producer and consumer. The supply and price stabilization perpetrated to protect the income of farmer, fisherman, business man, also to maintain the consumption affordable to main food ( Article 55). Stabilization of supply and price perpetrated by doing the regulation between export and import food (Article 56 ).

Examine these provision, it concluded that both preventive and repressive protection regarding farmer rights as subject in global trade still not optimum. It seen from the training done by government still in general way which training to reach a well marketing, not in specific way so the farmer can export and import independently, not depends to the third parties (broker) who precisely obtain its huge advantages, farmers only obtain small part of its benefit, even disadvantages.

Neutral position and farmer competitiveness in global trade is part of government impeller to impose Protection Farmers Regulation, with the philosophy that each of people of Indonesian, has right to achieve welfare. Furthermore, each of people of Indonesian has right and obligation, with its ability, to participating in development of trade to increase the welfare, agriculture in specific way. One of its purposes is directing to develop the most of farmers welfare. During this time, farmers already provide real contribution to support in agriculture development and rural economic development. Farmer as the perpetrator of agriculture development 
must be protected to support the fulfillment of national food to implement food sovereignty, food autonomy, and sustainable food endurance. Farmer in general has a weak position to reach production facilities, funding, and market access.

By that, in order to implement the protection and empowerment of farmer, an integrated regulation required. Protection and empowerment farmer including, strategy, Farmer protection, Farmer empowerment, funding, supervision, and society contribution, autonomy, advantages, alliance, integration, transparency, efficiency, and sustainable.

Protection legal politics and empowerment of farmers directed to policy which able to protect the business of farmers, among other, regulation of food commodity export in accordance with harvest session and/or the domestic consumption needs: provision of production facilities in proper time, proper quality, affordable: agriculture import fare, also commodity determination from domestic and foreign country.

Besides the protection policy to farmers, empowerment endeavor has a matter contribution to reach farmer welfare. Empowerment done in order to support and develop the paradigm of farmer, increase the business, also to grow the institutional which able to compete in global trade.

Several action are expected will be able to stimulate farmers being capable, as an education and training, counseling, supply, science access, technology, information, farmers institutional.

Farmers protection and empowerment aims to support sovereignty and autonomy of farmer regarding to achieve welfare, quality, and a better life: protecting farmer from failures: providing facilities which needed to improve farmers business: growing the ability and capacity also the institutional in order to reach productive business, developed, modern, capable, also providing legal certainty to farmers. 
Farmer Protection and Empowerment regulation referred to: Farmer Protection is a procedure to help farmers regarding to experience issues in facilities, business certainty, price risks, harvest failure, and climate changes. Farmer Empowerment is a procedure to increase the ability to implement a better farmers business through education and training, counseling, agriculture facilities development, consolidation, science access, technology and information, and also agriculture institution. Meanwhile, farmer is a people of Indonesian individually and/or with his/her family who implement farmer business in food plants, horticulture, plantation, and/or animal husbandry.

According to farmer protection to farmer as a subject in global trade, a few of regulation appropriate to be the legal rules, as the next following.

1. Farmers Protection and Empowerment based on a faulty : sovereignty, autonomy, advantages, togetherness, integration, efficiency, sustainable ( Article 2)

2. Farmers Protection and Empowerment aims to : implement the integration and autonomy in order to develop Farmers welfare, quality, and a better life, providing agriculture facilities, providing agriculture business certainty, protecting farmers from fluctuation, high cost economic activity, and crop failure, increase the ability and capacity of farmer also productive institutions, developed, modern, and sustainable, also to grow agriculture funding which serve the purposes of agriculture business. (Article 3 )

3. The strategy of farmer protection perpetrated through: facilities and agriculture production, business certainty, agriculture commodity prices, obliteration of high cost economic activity, crop failure, early warning system and effect from climates changes, agriculture assurance.

4. The strategy of farmer protection perpetrated through : education and training, counseling and mentoring, development of agriculture facilities, consolidation, funding, science access, technology and information, and agriculture institution. ( Article 17). 
5. Government has an obligation to create situation which generate profitable agriculture commodity price. These obligation perpetrated through set of : import fare, administrative requirements and quality, structure of product, and policy of food price stabilization.( Article 25)

6. Government create agriculture commodity which charged by import fare. The quantity of its fare stipulated by government based on the regulation. Government create the quantity of its fare according to : International trade fare, domestic trade fare, National and regional agriculture commodity, production and national necessity. ( Article 26)

7. Determination of agriculture commodity location must considering: Domestic agriculture commodity region, the integrity of installation according to regulation.( Article 28)

8. Each community who import the agriculture commodity must through the location that already stipulated by government.

9. Each community are prohibited to import agriculture commodity when the availability of domestic agriculture commodity already sufficient. ( Article 30)

10. Each agriculture commodity must qualified the administrative requirements and quality standard. The administrative requirements at least consists : import letter of permission, date of production and expired, also license from both countries.

11. Governments and local governments appropriate with its authority has an obligation to protect the agriculture business conducted by the farmers in agriculture assurance. The assurance in order to protect farmer from crop failures as a consequences from : illness from animals, pest, climate changes, and/or another risks regulated in Minister Regulation ( Article 37).

12. Governments and local governments with its authority facilitate each farmer as a participant of agriculture assurance. These facilitate including : the ease of registration, assurance company, socialization, and/ or assistance in premium payment. (Article 39)

13. Government and local governments with its authority has an obligation to organize education and training to farmer. Education and training consists : 
development of apprenticeship, scholarship for farmers in agriculture, or agriculture business training. (Article 42)

14. Counseling and mentoring are conducted in order to do : cultivation, postharvest, processing, a good marketing both to analyze the business and partnership with the traders man. (Article 46)

15. Government and local government with its authority has an obligation to facilitate funding and capitalization of agriculture business. These facilitate in order with : loan capital to own or extending the land ownership, subsidization to farmer. ( Article 66)

16. In order to implement the farmer protection and empowerment, government ordered to BUMN sector banking and local government ordered to BUMD sector banking according to serve the agriculture business. Services conducted by agriculture special unit executed with easily procedure and requirements. ( Article 84)

17. To conducting the distribution of credit and/or agriculture funding, bank actively support farmer in order to satisfy the requirement of credit and/or funding. Furthermore, bank actively help and facilitate farmer to its facility. Bank is being able to channeling credit and/or subsidy funding for farmers business through its institution not bank and/or institution in micro funding on agribusiness. (Article 86)

18. Implementation of farmers protection and empowerment, governments and local governments ordered government institution to serve farmers and /or their business to achieve the funding in accordance with its regulation. The institution must carry out the business payment simple and quickly. Moreover, the institution must help farmer to fulfill the requirement of funding. These institutions are being able to distributing credits and/or subsidized funding to the farmer to improve the agriculture sector. (Article 88-90)

19. Community being able to participating in farmer protection and empowerment. The participation can be done individually or in group. Contributions consists :drafting and planning, farmers protection, farmers empowerment, funding, and 
supervision. Community in protecting farmer also can contribute in : maintain and providing agriculture facilities, prioritizes the production of agriculture, providing social assistance to farmer, reporting if there's any violation according to its regulation. Community in farmers empowerment also can participate in : informal education, training and apprenticeship, mentoring, strengthening of agriculture institution, providing the funding facilities, and/or providing the access facility to information. (Article 95-98).

Considering the regulation, therefore legal protection, both preventive and repressive to the farmers as a subject of global trading merely to the provisions governing import. Import duty indeed bring profit, such as "increases to the government revenues" ( Widyawati, 2014:125 ), and "increases to the farmers revenue from rice production" ( Haryati, 2010:194 ). However, it has potential to harm consumers ( Hardono, 2004; and Febriyanti, 2012 ), and the largest consumers are farmers. Other provisions not directly nor specifically regulate legal protection to the farmers. Insurance can only provide protection to the farmers in case of force majeure such as crop failure, pest attack, or natural disaster. Insurance is not used to anticipate when the farmers failed to export or suffered losses because of the things that can not be predicted. Similarly, regarding the capitalization and financing of farming, there is no provision that stipulated clearly about capitalization, financing, or incentive, if farmers would export. Designated banking had not yet penetrated specifically on export-import services. Though banks are encouraged to facilitate credit but on the other hand "banks apply the precautionary principle rigorously" (Ashari, 2009: 21). Education, training, and mentoring that planned and executed is still limited to improve the competence of farmers in national marketing, not specifically in the fields of global trade of export-import. Lastly, the provisions regarding public participation are also not encouraged to make the farmers as the subject in global trading. There is no specific provision which oblige business actors who have entered global market to collaborate and encourage farmers to do export- 
import, so that farmers can have bargaining power and competitiveness as a subject in global market.

Prospect on making farmers as subject in global trading also stipulated in Trading Act, trading activity is a major driver of national economic development that provides support to increase production, create jobs, increase exports and foreign exchange, spread income, and to strengthen the competitiveness of the domestic products for the benefit of the country. Based on the objectives and principles, Trading Act contains subject matter in accordance with the scope of the regulation that covers Domestic Trade, Foreign Trade, Trade Border, Standardization, Trade through the Electronic System, protection and security of Commerce, the empowerment of cooperatives and micro, small, and medium enterprises, development of exports, International Trade Cooperation, Trade Information System.

Trade is the order of the activities related to the transaction of goods and / or services in the country and beyond the borders of the country with the purpose of transfer of rights to the Goods and/or Services to obtain rewards or compensation. Foreign trade is trade that includes the export activities and / or import of Goods and/or Services beyond the borders of the country. Exports are issued Goods activities of the Customs Area. Exporter is an individual or institution or business entity, either in the form of legal entity or legal entities, which do export. Imports in an activity of Goods into the Customs Area. Importer is an individual or institution or business entity, either in the form of legal entity or legal entities, which do import. International trade cooperation is the Government's activity to promote and secure the national interests through trade relations with other countries and/or institutions/international organizations.

According to the provisions, it can be identified that farmers is a subject of global trade that should get legal protection of the Trade Law, hence their bargaining position and their competitiveness can be improved. However, it is necessary to assess the provisions contained in the Trade Law have contributed to the protection of 
farmers as a subject in global trade. Several articles relating to the issue of legal protection for farmers as the subject of global trade described as follows.

1. Trade policy is based on the principle: national interest, legal certainty, fair and healthy, business security, accountable and transparent, independence, partnerships, expediency, simplicity, togetherness, and environmentally sound (Article 2)

2. Setting trade activities aimed at: increase national economic growth; improving the use and Trade Domestic Product; increase business opportunities and create jobs; ensure smooth distribution and availability of basic needs goods and essential goods; improve facilities and infrastructure Trade; promoting partnerships between large enterprises and cooperatives, micro, small, and medium enterprises, as well as government and private; improve product competitiveness and national efforts; improve the image of Domestic Product, market access, national exports; increase trade based product creative economy; improve consumer protection; increase the use of SNI; improve the protection of natural resources; and improve oversight of Goods and/or Services that are traded (Article 3).

3. The Government shall regulate the activities of foreign trade through policies and control in the field of export and import. Policies and Foreign Trade Control referred to in paragraph (1) shall be directed to: improving the competitiveness of Indonesian export products; improvement and expansion of market access abroad; and exporter and importer increased ability to become a reliable business communities. Foreign Trade Policy at least include: increase in the number and the type and value-added export products; the harmonization of standards and procedures for trade activities with trading partners; institutional strengthening in the foreign trade sector; development of facilities and infrastructure of Foreign Trade; and protection and national security interests of the negative impact of foreign trade. Foreign Trade 
Control include: licensing; standards; and prohibition and restriction ( Article 38 ).

4. Exports of Goods carried by the business communities that have been registered and established as Exporter, unless otherwise determined by the Minister ( Article 42 ). Exporter solely responsible for the goods exported. Exporters are not responsible for the exported goods referred to in paragraph (1) subject to administrative sanction in the form of revocation of license, approval, recognition, andor determination in the field of trade (Article 43 ). Import Goods can only be done by importers who have the identifier as importer based on the determination of the Minister. In certain cases, for import of Goods can be carried out by importers who do not have an identifiers as an Importer ( Article 45). The importer solely responsible for the Goods imported. An Importer who is not responsible for the imported Goods referred sanctions in the form of revocation of license, approval, recognition, and/or determination in the field of trade (Article 46).

5. For the Export and Import activities, Minister obliging Exporters and Importers to have a permit, in a form of approval, registration, confirmation, and/or recognition. Minister obliging Exporters and Importers to have a permit to do temporary export and temporary import (Article 49 ). All Goods can be exported or Imported, unless prohibited, restricted, or otherwise provided by law. The Government banned the Import or Export Goods to the national interest by reason of: to protect national security or public interest, including social, cultural, and moral society; to protect intellectual property rights; and/or to protect the health and safety of humans, animals, fish, plants, and the environment ( Article 50).

6. Exporters are prohibited from exporting Goods that defined as Goods that are prohibited to be exported. Importers are prohibited from importing Goods that defined as Goods that are prohibited to be imported (Article 51). Exporters are prohibited to export Goods which are not in accordance with the provisions of Goods for export restriction. Importers are prohibited to import 
Goods which are not in accordance with the provisions of Goods for import restriction. Restricted goods shall be determined by the regulation. Each exporter who exports goods which are not in accordance with the provisions of Goods for export restriction subjected to administrative sanctions and/or other sanctions stipulated in the legislation. Each Importer who import goods which are not in accordance with the provisions of Goods for import restriction subjected to administrative sanctions and/or other sanctions stipulated in the legislation (Article 52).

7. The Government may limit the export and import of Goods to national interest by reasons of: to protect national security or public interest; and/or to protect the health and safety of humans, animals, fish, plants, and the environment. The government may limit the export of goods by reasons of: ensure the fulfillment of domestic needs; ensure the availability of raw materials needed by the processing industry in the country; protect the sustainability of natural resources; increase the economic value of raw materials and/or natural resources; anticipating a drastic price increase of certain export commodities in the international market; and/or maintain the stability of certain commodity prices in the country. The government may limit import of goods by reason of: to build, accelerate, and protect certain domestic industries; and/or to maintain the balance of payments and/or the balance of trade (Article 54).

8. The Government shall provide assistance to businesses communities in order to develop exports for expansion of market access for Goods and Services produced domestically. Such development may be in the form of incentives, facilities, information, market opportunities, technical guidance, as well as promotion and marketing assistance for export development (Article 74). In order to expand market access for goods and/or services of domestic production, the Government and/or Regional Government is obliged to introduce the Goods and /or Services by means of: trade promotion held in the country and/or abroad; and/or participate in the trade promotion in the country and/or abroad. Trade promotion can be: trade shows; and trade 
missions. Trade promotion in the form of the exhibition include: international trade fairs; national trade fairs; or local trade shows.

9. Government in conducting trade shows abroad involving cooperatives and micro, small, and medium enterprises. Trade missions carried out in the form of an international business meeting to expand export opportunities. The trade mission is done through visit by Government, Local Government, business communities, and/or other institutions from Indonesia to overseas in order to conduct business activities or improve the trade relations between the two countries (Article 75). Implementation of trade promotion abroad by the Government, Local Governments, institutions other than Central / Regional Government, and/or businesses communities conducted in coordination with the Representative of the Republic of Indonesia abroad in the country concerned (Article 76)

10. The Government and/or Local Governments can provide facilities and /or ease of implementation of the trade show conducted by businesses communities and/or institutions other than the Government or the Logal Government in accordance with the provisions of the legislation. The provision of facilities and/or ease of implementation of the trade show is given to: organizer of the national trade promotion; and participant other than the Government and/or the regional government and national business communities. Government and Local Government support each other in doing trade shows to develop the export of national commodities.

11. In addition to the trade promotion, to introduce the Goods and/or Sservices, should be supported by imaging campaign in Indonesia and abroad. Implementation of Indonesian imaging campaign can be done by the Government, Local Government, institutions other than Central/Regional Government, and/or business communities individually or together. Implementation of Indonesian imaging campaign by the Government, Local Government, institutions other than Central/Regional government, and/or foreign business communities in coordination with the Representative of the 
Republic of Indonesia in Foreign Affairs in the country concerned (Article 79).

12. To improve market access and to protect and secure the national interest, the Government may conduct trade cooperation with other countries and/or institutions/international organizations. Trade cooperation can be done through international trade agreements (Article 82). Government's tasks in the field of trade include: formulate and determine policies in the field of trade; formulate national standards; formulate and establish norms, standards, procedures, and criteria in the field of trade; establish a licensing system in the field of trade; control the availability, price stabilization, and distribution at basic needs and/or essential goods; carry out international trade cooperation; manage information in the field of trade; to provide guidance and supervision of activities in the field of trade; encourage the development of national export; create a conducive business climate; develop a national logistics; and other duties in accordance with the provisions of the legislation (Article 93).

13. The government in carrying out tasks shall have the authority: granting licenses to business communities in the field of trade; implement the harmonization of trade policy in the country in order to improve the efficiency and effectiveness of national distribution system, order in trade, market integration, and business certainty; cancel the policy and regulation in the field of trade established by the Local Government as opposed to government policies and regulations; imposed restrictions and/or limitation on Trade in Goods and/or Services; developing a national logistics to ensure availability of basic goods and/or essential goods; and other authority in accordance with the provisions of the legislation (Article 94).

14. Local Government in charge of: implement government policies in the field of trade; implement licensing in the fields of trade in the region; control the availability, price stabilization, and distribution of basic needs and/or essential goods; monitor the implementation of international trade cooperation in the region; manage information in the field of trade in the region; provide 
guidance and supervision of activities in the fields of trade in the region; encourage the development of national exports; create a conducive business climate; develop regional logistics; and other tasks in the field of trade in accordance with the provisions of the legislation (Article 95).

15. Local Government in carrying out tasks shall have the authority: establish policies and strategies in the field of trade in the region in order to implement government policy; granting licenses to businesses in the field of trade delegated by the Government; managing information in the area of trade in the course of trade information systems; guidance and supervision of trading activities in the local area; Another authority in the field of trade in accordance with the provisions of the legislation. Implementation of Local Government authority should be in accordance with the policies established by the Government (Article 96).

Examine the provisions of the Trade Law related to international trade, in this case the export-import, not found in favor of farmers setting as a subject in global trade. This raises questions regarding Indonesia as agrarian country, with a population of the majority of farmers, and agricultural products, especially food as the supreme of exports in Indonesia. There are no special programs to introduce by farmers. Exhibitions and trade shows are dominated by non-agricultural products. Similarly, an increase in competitiveness. Farmers' Competence have not improved in particular, merely can do marketing, has not been given special training and assistance so that farmers can carry out export and import independently. The financing facility in the Trade Law is still emphasis on incentives imports, not increase the incentives for export activities.

\section{CLOSING}

From the studies that have been elaborated, it can be drawn the conclusion that the legal protection, both preventive and repressive, which is given by the Food 
Law, Protection and Empowerment of Farmers Law, as well as the Trade Law, to protect and make the farmers as the subject of global trade with high bargaining position and high competitiveness, has not been optimal. This is because the provisions governing the farmer as a subject in global trade has not regulated specifically. There should be a specific regulation considering Indonesia as an agrarian country, the majority of the population are farmers, and agricultural commodities are still a superior of Indonesia's exports.

\section{E. RECOMMENDATION}

Government, business communities, and society need to aligned more to farmers and their farm s pursuant to each capacity. Government needs to give farmers more opportunity to improve their competence, especially in the export-import, through training and mentoring that more intensives. To the business communities, in particular to them that has succeeded in doing export-import, invite collaboration with farmers according to the principles of mutual respect and dignity, mutual benefit, and fair. To the society, they can aligned more to farmers by using more of the products produced by the farmers themselves through farming. Recommendation to the academics, to improve studies of law in the field of agriculture, therefore will be born discipline of agricultural law, which may be a reference in the preparation of legal products in agriculture, especially to protect farmers, and improve the bargaining position and competitiveness in the global market.

\section{F. ACKNOWLEDGMENTS}

Thanks and appreciation to Ministry of Research, Technology and Higher Education of the Republic of Indonesia that has funded this research with the budget 2017 , that this article is one of the outputs. To all those who have helped the implementation of this study, I thank you profusely. 


\section{BIBLIOGRAPHY:}

Books:

Asian Law Group Pty.Ltd. 2013. Hak Kekayaan Intelektual: Suatu pengantar. Bandung: Alumni.

Bambang Irawan.2014. Memperkuat Daya Saing Produk Pertanian. Jakarta: Badan Litban Pertanian. IAARD Press

Setjen DPR RI. Permasalahan dan Upaya Peningkatan Produktivitas Pertanian. Biro Analisa Anggaran dan Pelaksanaan APBN DPR RI.

Sri Hery Susilowati, dkk. 2009. Strategi Penumbuhan dan Proteksi Sektor Pertanian. Pusat Analisis Sosial ekonomi dan Kebijakan Pertanian Badan Penelitian dan Pengembangan PERtanian Departemen Pertanian.

Journal:

Ashari. 2009. "Optimalisasi Kebijakan Kredit Program Sektor Pertanian di Indonesia”. Analisis Kebijakan Pertanian Volume 7 No.1, Maret.

Haryati, Yuli, dan Iqnatia Martha Hendrati. 2010. "Ekonomi Perberasan: Keterkaitan Pasar Beras Dunia Dengan Pasar Indonesia”. Jurnal Mitra Ekonomi dan Manajemen Bisnis, Vol. 1, No. 2, Oktober 2010.

M. Zainul Abidin. 2015. "Dampak Kebijakan Impor Beras dan Ketahanan Pangan dalam Perspektif Kesejahteraan Sosial”. Sosio Informa Vol. 1 No. 03. September - Desember.

Siti Asfiyah. 2015. "Perlindungan Hukum Potensi Indikasi Geografis di Kabupaten Brebes Guna Pengembangan Ekonomi Masyarakat Lokal”. Jurnal Idea Hukum Vol. 1 No. 2 Edisi Oktober 2015 Magister Hukum Fakultas Hukum Universitas Jenderal Soedirman. 
Widyawati, Wiwit, Syafrial, dan Moch. Muslich Mustajab. 2014. "Dampak Kebijakan Tarif Impor Beras Terhadap Kinerja Ekonomi Beras di Indonesia”. Jurnal Habitat, Volume XX. No. 2. 